Notes on a Collection of Bronze Weapons, Implements and Vessels Found at Khinámán to the West of Kermán in South-East Persia, by Major P. Molesworth Sykes, C.M.G.

Author(s): Canon Greenwell

Source: The Journal of the Royal Anthropological Institute of Great Britain and Ireland, Vol. 37 (Jan. - Jun., 1907), pp. 196-200

Published by: Royal Anthropological Institute of Great Britain and Ireland

Stable URL: http://www.jstor.org/stable/2843254

Accessed: 05-11-2015 11:59 UTC

Your use of the JSTOR archive indicates your acceptance of the Terms \& Conditions of Use, available at http://www.jstor.org/page/ info/about/policies/terms.jsp

JSTOR is a not-for-profit service that helps scholars, researchers, and students discover, use, and build upon a wide range of content in a trusted digital archive. We use information technology and tools to increase productivity and facilitate new forms of scholarship. For more information about JSTOR, please contact support@jstor.org.

Wiley and Royal Anthropological Institute of Great Britain and Ireland are collaborating with JSTOR to digitize, preserve and extend access to The Journal of the Royal Anthropological Institute of Great Britain and Ireland. 


\section{NOTES ON A COLLECTION OF BRONZE WEAPONS, IMPLEMENTS AND VESSELS FOUND AT KHINÁMÁN TO THE WEST OF KERMAN IN SOUTH-EAST PERSIA, BY MAJOR P. MOLESWORTH SYKES, C.M.G.}

By Canon Greenweld, M.A., I.C.L., F.R.S., F.S.A.

With an Introductory Note by Major Sykes.

[With Plate XXI.]

INTRODLCTORY NoTE.

I PROPOSE, in the first place, to give a brief account of how the collection cime into my possession. For some years I had been holding the post of Consul at Kermán in South-east Persia when, in 1900, a Persian friend, the Governor of Khinámán, a sub-district of the Kermán province, situated some forty miles to the west of Kermán city, wrote me a most interesting letter. He informed me that, while trenching ground preparatory to planting a garden, he had come on a quantity of bronze and copper objects and that he hoped that I would come over and see what he had found. As the district was entirely unexplored, in addition to the chance of making interesting archæological discoveries, I accepted the invitation and reached Khinámán shortly after.

The find was made near the hamlet of Kákh, situated on the slope of a low ridge. Further south is a high hill, on which we saw the ruins of an important fortress, known as the Kala-i-Dukhtar or "Virgin Fort," and beyond, a huge gravel slope forms the northern side of a valley up which runs the main road from Kermán to Yezd. Owing to a fine stream of water, Kákh and the surrounding villages were evidently always of some importance in a land where cultivation depends on irrigation, and this theory is confirmed both by the size of the ruined fort and by important but more modern ruins. The only legend peculiar to the district is that Aza Mahán-the founder of Mahun under Noshirwán-was also Governor of Khinámán, and that, at the time of the Arab conquest, in the seventh century A.D., seven warriors mounted on bulls were sent to aid hapless Yezdijvid, the last monarch of the house of Sás-án.

To come to the actual collection, the long thin rods puzzle Canon Greenwell and myself. Persians, however, suggest that they were placed in the armpits of the corpses as sticks of the pomegranate are placed to-day. The bowls are also of considerable interest. The smallest one can be identified by the fact that most Persians use its identical counterpart to-day. It is, in fact, a pocket drinking vessel. As to the vessel with a spout it seems at least possible that it may have been a lamp, although rather deep.

I believe that I obtained specimens of everything that was found, except a silver carving which was melted down before I could rescue it. 
This concludes anything that I can add to the able paper which Canon Greenwell has written, and I only hope that his paper may ultimately be of service in our efforts to throw light on the dim past of Persia. ${ }^{1}$

P. M. S.

The weapons and other articles were found in the district of Khinámán, in the province of Kermán, not many miles west of the town of the same name, in the south-eastern part of Persia. They had been associated, as grave goods, with burials of unburnt bodies, which had gone entirely to decay, in a cemetery of no great extent. The graves, which were discovered accidentally, were situated at the foot of a ridge. There was no sign that a mound or any added earth had ever been placed over the graves, nor was there anything on the surface to indicate the existence of the burials beneath, which had been made close tngether. The graves, more or less square in form, which had been sunk to a depth of from 3 feet to 4 feet into the ground, had neither been lined nor corered with stones.

The discovery was made by ordinary workmen, to whose recollection Major Sykes, who only became acquainted with the find some months after it was made, is indebted for any facts which have been preserved in connection with the burials. They are but scanty and otherwise insufficient, but each grave contained, it is said, a large vessel of pottery and two pins of a metal, which appear to be, as were all the other metallic objects, constituted of copper with a small addition of tin, an inferior kind of bronze. Besides the larger vessels of pottery, which were too big to remove, two much smaller ones, well made and slightly ornamented, have keen preserved; one of them, quite similar in all respects to the other, is illustrated. The larger vessels were of great size and destitute of any ornamentation. They much resembled the pots, now called in Persia khom, and were capable, like those in which Ali Baba and the forty thieves were hidden, of containing a human body. They were of a globular shape, somewhat elongated, standing on a flat bottom with a wide mouth. They measured about 4 feet in height and were $2 \frac{1}{2}$ feet wide at the middle. These vessels were probably the receptacles of the corpse, as was the case in burials in other parts of the world, as for instance in Asia Minor, Spain, etc. Nothing was found in them except some yellowish dust, all that was left of the interred body, supposing they originally contained one, nor in the graves themselves was any portion of human or animal bone discovered.

So far as is known no similar cemetery or burials of a like kind have hitherto been found in Persia.

It is impossible to over-estimate the interest and value of this discovery. This arises not only from the nature of the articles themselves, but also from the

'Illustrations of the find appear in my "Ten Thousand Miles in Persia," in Journal Anthrop. Inst., vol. xxxii, 1902, p. 341 ; and in Archoologia, vol. 1viii, pp، 8-16. 
light it throws upon the early metallic stage of cultivation in that country, about which our information is very scanty.

Before giving a description of the various articles, it may be well to say something in regard to their purpose and use, as well in connection with the living as with the dead. The axes and spear or javelin heads are weapons of war or of the chase, and were placed in the grave in accordance with a practice which has prevailed largely over many parts of the Old and New Worlds, the belief that the buried person would require in an after life those things which had been necessary for existence in that which had already been passed through. The pins and armlets are personal articles connected with dress or ornament. The knives were for ordinary domestic use, but what was the purpose of the long thin rods with a curved termination it is at present difficult to explain. The bowls, which had no doubt been of use in the economy of the household, were probably the receptacles of food for the sustenance of the late owner in another world, and correspond to the vessels of pottery which in other countries fulfilled a similar purpose. The same use may be assigned to the smaller vases of clay, which most likely held liquid.

These vases, of which two have come into Major Sykes' possession, are of similar size and shape, and are similarly ornamented. They are globular in form, of thin fabric, lathe-turned, and apparently baked in a kiln. They have a short narrow neck, $1 \frac{3}{4}$ inches high, which expands at the mouth to a width of 2 inches. Their height is $7 \frac{5}{8}$ inches, and they have a flat bottom $4 \frac{1}{2}$ inches wide. The ornamentation is confined to the upper part of the body of the base immediately beneath the neck and occupies a space of 2 inches in depth. It consists of three encircling bands, of a rather roughly-made zigzag pattern, which increases downwards in width from $\frac{5}{8}$-inch to $\frac{7}{8}$-inch. The bands are divided from each other and are bordered at top and bottom by a plain grooved line. The design seems to have been made by drawing a bluntly-pointed tool over the moist clay before it was fired.

Five bowls have been preserved, four of which are of the same general shape. They are made of hammered copper, and are, on the whole, somewhat globular in form, but varying to some extent. In height they range from $1 \frac{3}{4}$ inches to 6 inches, and are from $3 \frac{3}{4}$ inches to 6 inches wide at the mouth. They stand on a flat circular bottom, about 2 inches wide, from which, except in one case, the sides rise after the fashion of steps, from one to three in number. The fifth, which is $2 \frac{1}{2}$ inches high, and $3 \frac{1}{8}$ inches wide at the mouth, with one step at the bottom, is provided with a handle $2 \frac{1}{4}$ inches long, having a channel along its length, which may also have served as a spout. The two knives are quite different in form; one, which has lost a portion at the end of the blade, is now 6 inches long and $\frac{7}{8}$-inch wide, with a flat narrow tang, which occupies $1 \frac{3}{4}$ inches of the whole length of the knife, and is prolonged down the blade in a flat rib $\frac{3}{8}$-inch wide; the other, of very thin fabric, is in shape a narrow oval, $4 \frac{7}{8}$ inches long and $1 \frac{5}{8}$ inches wide, with a sharp edge all round it. Neither of them are very different from similar implements of the Bronze Age, which have occurred elsewhere. The two pins are very much alike in every way; 
one is $7 \frac{3}{4}$ inches long, the other $6 \frac{7}{8}$ inches. The head in each case is a flat circular disc, grooved round the edge by vertical lines, and having a round plain projection on the top. Immediately beneath the head are two grooved saltires, side by side, placed between two lines above and two beneath, the whole being in one case $1 \frac{1}{8}$ inches deep, in the other $\frac{3}{4}$-inch. The two armlets are penannular and quite plain, 3 inches and $2 \frac{1}{4}$ inches respectively in diameter, and might have come from any country where bronze was used for such ornaments. The two enigmatical rods with curved ends are of about the same length, $18 \frac{1}{4}$ inches and $18 \frac{5}{8}$ inches. They differ, however, in some slight particulars. The longest is round at the part which may be called the handle end, though it becomes square for the space of an inch at the end itself, where it expands a little, apparently by having been beaten out as a rivet would be when hammered. It is square in section, for a length of above 11 inches at the curved end, and finishes at the point of the curve in a cutting edge. The other is round throughout and expands at either end in the same way as does the first at the handle end. What these rods may represent it is difficult to say, but it is possible they may have been emblems of direction, control, and power, in other words, the shepherd's crook, and have been carried by or before the chief, the symbol of his authority over the tribe or community which he ruled.

The javelin heads are leaf-shaped, with a tang for handling, and are not very different from others which have been found in various parts of the world. One is $4 \frac{7}{8}$ inches long, of which the tang occupies $2 \frac{1}{8}$ inches, and $1 \frac{1}{8}$ inches wide, with a sharp rib down the centre of the blade; the other is $4 \frac{1}{4}$ inches long, the tang being $1 \frac{1}{8}$ inches, and $1 \frac{1}{8}$ inches wide, with a flatter rib down the centre than has the first.

Of the various articles discovered in the cemetery the axes are the most important and noteworthy. It has not been possible to ascertain if any other grave goods were associated with them, with the exception of the large pot which had contained the body. They are described as axes, but it must not be understood that they were weapons or implements to be employed in war or for other useful purpose. The way in which the handle was passed through the blade precludes the possibility of their having served as cutting instruments, though one of the ends is to some extent sharp-edged. It is probable they were representative weapons made to be buried with the dead person in place of that which had been used by him in life, or, as is perhaps more probable, they were of a ceremonial nature, to be employed in processional rites, or to be carried as a mark of dignity before a man of rank and power in the community. In general form they are much alike, and are double-ended, with a hole for the handle about the middle, and a peculiar curve towards the narrower end. One end is curved, wide-spreading and blunt, the other end is much narrower and sharp at the curved edge. The larger is 7 inches long, the blunt end being $3 \frac{5}{8}$ inches wide across the curve, the sharp end $1 \frac{5}{8}$ inches wide. The socket for the handle, which passes diagonally through the blade, is nearer the blunt than the sharp end. The upper edge of the socket, which is $\frac{5}{8}$-inch by $\frac{3}{8}$-inch, appears to represent the open mouth of a lion; the lower edge, which is acutely pear-shaped, $1 \frac{3}{4}$ inches by $\frac{1}{2}$-inch, may roughly 
represent part of the body of the same beast. Both edges of the socket are bordered by a band of small round bosses. Between the ends of the socket is a sharp-pointed oval raised figure, divided along its length by a similarly shaped groove, parallel to the sides of the figure. It may be a representation of the human eye. Just above the pear-shaped lower edge of the socket is a narrow sharp-ended oval groove, which is perforated, at the end nearest to the sharp edge of the axe, by a small similarlyshaped hole. Immediately beneath the eye-shaped figure, on one face of the axe, is a small round hole drilled, in a gradually narrowing way, through into the socket. The edge of the blunt end of the axe is ornamented with two parallel bands of projections; the outer one consists of loops, which are joined at the top, and form a kind of wavy pattern, the inner one having a series of round balls similar to those which surround the edges of the socket.

The second axe, which is a still more interesting one, is 6 inches long, the blunt end being 3 inches wide, the sharp end $1 \frac{1}{2}$ inches wide. The socket for the handle, though it has not so diagonal a passage as that of the first axe, does not pass straight through. Each edge of the socket, the upper one being $\frac{1}{2}$ inch by $\frac{1}{4}$ inch, the lower 1 inch by a little more than $\frac{1}{4}$ inch, is bordered by two bands of short, narrow oblong projections. Occupying the same position as that on the first axe is a similar pointed oval eye-like figure, which has a border of projecting oblongs smaller than those at the edges of the socket. In the same place as the opening through the blade in the first axe, and beneath the hind quarters of the grotesque beast, presently to be noticed, and close to the edge of the blade is a small oblong hole which perforates it. The edge of the blunt end of the axe is ornamented with a band of triangular shaped hollows, their base being towards the edge, within that and parallel to it is a narrow band of straight lines of vertical punchings. Parallel to and near to the lower edge are two bands of slightly inclining linear punchings, each bordered by a thin engraved line. Upon the upper band are two triangular figures filled in with crossing lines. The whole of these punched or engraved lines are rudely executed. Standing over the socket is a winged grotesque, which has a beast's head with open mouth, topped by a curved crest and having a beard. Opposed to this creature, standing on the curve of the sharp end, is a lion apparently roaring at his adversary.

It will be observed that on both these axes the lion appears in whole or in part giving a distinctive character to the design. The lion occurs as a prominent feature upon two axes which come from places which may be treated as within the same area of Asia. They differ, however, in more than one particular from those illustrated, more especially in their having been instruments for use. One from Hamadan (Ecbatana) in Persia, in the British Museum, has the socket for the handle made through the mouth and part of the body of the lion. The other from Van in Armenia in my collection at Durham, has the lion, which is being baited by two dogs, seated upon the socket. They are described and figured in Archcoologia, vol..lviii. 
Journal of the Royal Anthropological Institute, Vol. XXXVII, 1907, Plate XXI.

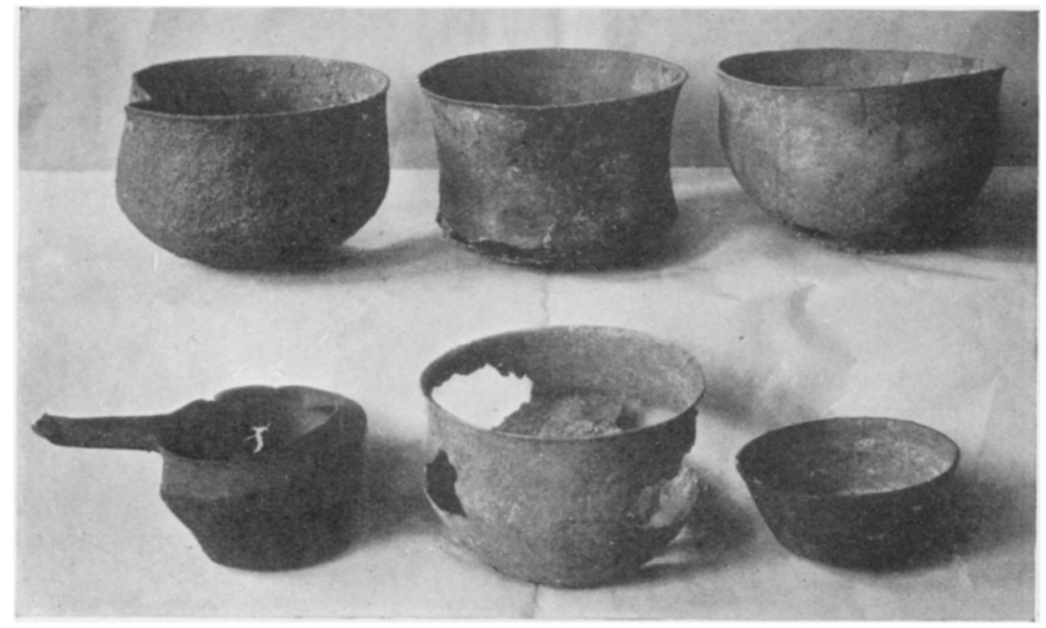

FIG. 1.-POTS.

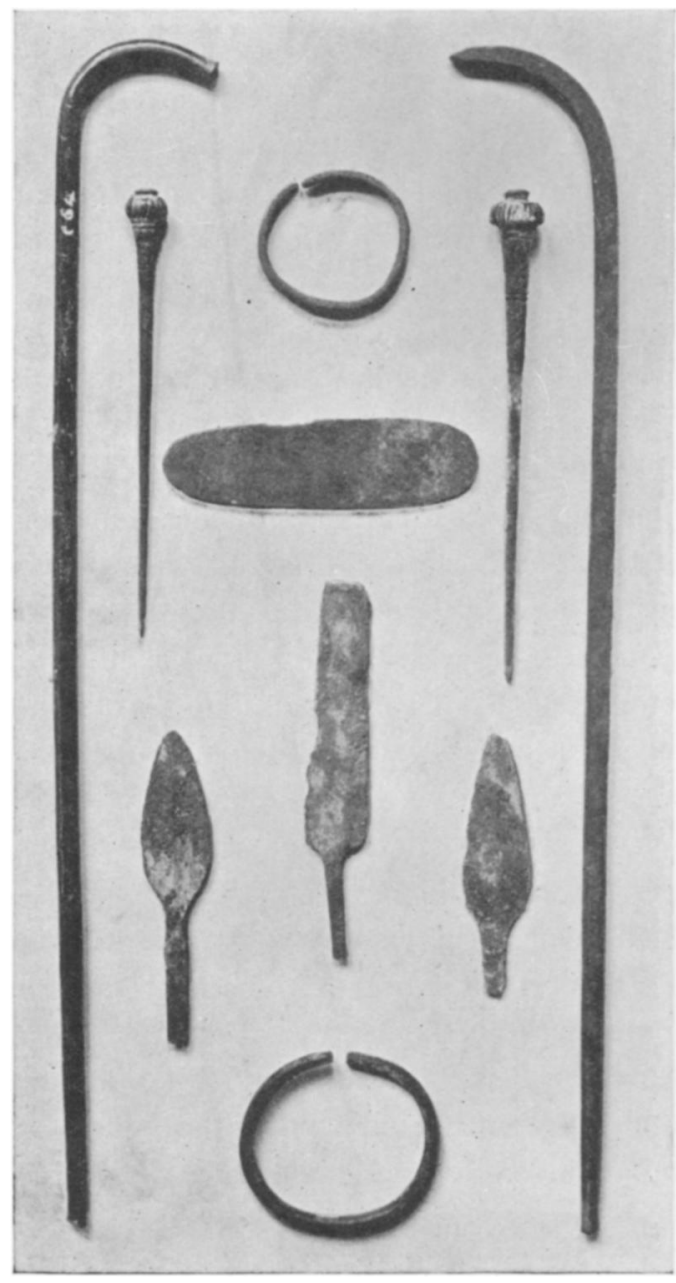

FIG. 2.-VARIOUS OBJECTS.

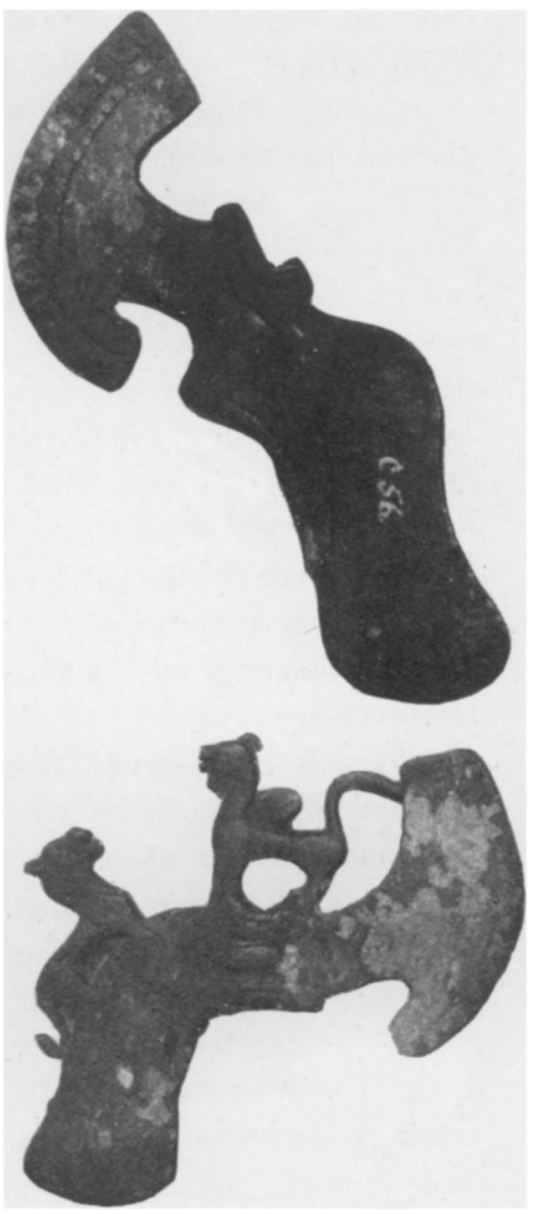

FIG. 3.-AXE HEADS.

BRONZE WEAPONS, IMPLEMENTS, AND VESSELS FOUND AT KHINÁMÁN. 